\title{
The effects on digestibility and ruminal measures of chemically treated corn stover as a partial replacement for grain in dairy diets ${ }^{1}$
}

\author{
D. E. Cook, ${ }^{*}$ D. K. Combs, ${ }^{*}$ P. H. Doane, $\dagger$ M. J. Cecava, $\dagger$ and M. B. Hall $\ddagger^{2}$ \\ *Department of Dairy Science, University of Wisconsin, Madison 53706 \\ †ADM Research, Decatur, IL 62526 \\ ‡US Dairy Forage Research Center, USDA-Agricultural Research Service, Madison, WI 53706
}

\begin{abstract}
Alkaline treatment of gramineous crop residues can convert an abundant, minimally utilized, poorly digestible straw into a moderately digestible feedstuff. Given the volatile nature of grain prices, substitution of treated stover for grain was investigated with dairy cows to provide insights on ruminal and digestibility effects of a feed option that makes use of alternative, available resources. The objective of this study was to evaluate changes in diet digestibility and ruminal effects when increasing levels of calcium oxide-treated corn stover (CaOSt) were substituted for corn grain in diets of lactating cows. Mature corn stover was treated with calcium oxide at a level of $50 \mathrm{~g} \cdot \mathrm{kg}^{-1}$ dry matter (DM), brought up to a moisture content of $50 \%$ following bale grinding, and stored anaerobically at ambient temperatures for greater than $60 \mathrm{~d}$ before the feeding experiment. Eight ruminally cannulated Holstein cows averaging $686 \mathrm{~kg}$ of body weight and $35 \mathrm{~kg}$ of milk. $\mathrm{d}^{-1}$ were enrolled in a replicated $4 \times 4$ Latin square, where CaOSt replaced corn grain on a DM basis in the ration at rates of $0,40,80$, and $120 \mathrm{~g} \cdot \mathrm{kg}^{-1} \mathrm{DM}$. All reported significant responses were linear. The DM intake declined by approximately $1 \mathrm{~kg}$ per $4 \%$ increase in CaOSt inclusion. With increasing replacement of corn grain, dietary neutral detergent fiber (NDF) concentration increased. However, rumen NDF turnover, NDF digestibility, NDF passage rate, and digestion rate of potentially digestible NDF were unaffected by increasing CaOSt inclusion. Total-tract organic matter digestibility declined by 5 percentage units over the range of treatments, approximately 1.5 units per 4-percentageunit substitution of CaOSt for grain. With increasing
\end{abstract}

\footnotetext{
Received September 15, 2015.

Accepted March 21, 2016.

${ }^{1}$ Mention of any trademark or proprietary product in this paper does not constitute a guarantee or warranty of the product by the USDA or the Agricultural Research Service and does not imply its approval to the exclusion of other products that also may be suitable.

${ }^{2}$ Corresponding author: marybeth.hall@ars.usda.gov
}

CaOSt, the molar proportions of butyrate and valerate declined, whereas the lowest detected ruminal $\mathrm{pH}$ increased from 5.83 to 5.94 . Milk, fat, and protein yields declined as CaOSt increased and DM intake declined with the result that net energy in milk declined by approximately 1 Mcal per $4 \%$ increase in CaOSt. Time spent ruminating (min $\mathrm{kg}^{-1} \mathrm{DM}$ intake) increased with increasing CaOSt, though total minutes per day were unaffected. These insights on the effect of substitution of treated corn stover for corn grain may be used to predict the effect on nutrient supply to the cow over a range of substitution levels. The acceptability of the effect will depend on the economics of milk production and availabilities of feedstuffs.

Key words: corn stover, calcium oxide, alkaline, fiber digestibility

\section{INTRODUCTION}

Alkaline treatment of gramineous crop residues has been shown to be an effective method of enhancing digestibility of the secondary cell wall. The alkali agents are absorbed into the cell wall, where acetic and uronic acid ester bonds are saponified, breaking down linkages between lignin, hemicellulose, and cellulose (Jackson, 1977). Alkali agents also reduce the strength of intermolecular hydrogen bonds in cellulose fibrils, resulting in swelling of the cellulose (Jackson, 1977). These modes of action open up the cell wall and lead to increased bacterial adhesion to fiber particles and increased bacterial colonization, resulting in a greater degree of fiber degradation in the rumen. Previously, Haddad et al. (1994) demonstrated this effect with $\mathrm{NaOH}$ and $\mathrm{Ca}(\mathrm{OH})_{2}$ treatment of wheat straw, which resulted in in the potentially digestible NDF (pdNDF) increasing from 51.2 to $81.2 \%$ and $73.5 \%$, respectively, as a fraction of the total NDF. The rate of digestion was not affected and the in vitro lag time decreased with treatment. Others have also found increases in the extent of digestion of gramineous forages with alkaline treatments (Rexen and Vestergaard Thomsen, 1976; Wanapat et al., 1986; Canale et al., 1990). 
Recent interest in alkali treatment of corn stover has been focused on improving the quality and making use of this abundant, minimally utilized resource. Work in beef cattle showed that partial replacement of corn grain $(35 \%$ of diet DM) with a mix of calcium oxide $(\mathrm{CaO})$ treated corn stover and distillers grains had no effect on ADG or carcass characteristics (Russell et al., 2011). Donkin et al. (2012) found that in dairy cattle producing approximately $29 \mathrm{~kg}$ of milk daily, CaOtreated corn stover could replace up to $25 \%$ of corn silage (DM basis) with no effect on milk production, intake, and milk composition.

Alkali-treated stover would most likely be considered a substitute for forage and other fibrous feeds in dairy cattle diets, given its composition and physical form. However, during some years, limited forage availability and grain production (USDA, 2013a) or high grain prices (up to $\$ 570 / \mathrm{t}$ for corn grain; USDA, 2013b) force farmers to feed whatever feedstuffs are available to maintain their herds. A challenge in such cases is having information with which to estimate how feeds will perform in such diets with the larger, productive Holstein cows present on many farms today. Very limited information is available regarding the effect of substitution of fiber sources for grain in lactating cow diets (Hall and Chase, 2014), nor on the effect of alkalitreated stover used in such an exchange on digestibility and rumen function. Accordingly, the objective of this study was to evaluate the effects of partially replacing corn grain with $\mathrm{CaO}$-treated corn stover on ruminal measures, total-tract nutrient digestibility, and time management of lactating dairy cows.

\section{MATERIALS AND METHODS}

\section{CaO-Treated Corn Stover}

Corn stover was harvested in a large round bale format, following postgrain harvest dry-down, and was stored aerobically until treatment. At the time of treatment, bales were processed through a tub grinder (Haybuster Model H1100, Duratech Industries, Jamestown, ND) with a 10.2-cm screen. The processed stover was mixed in a TMR mixer, where a $\mathrm{CaO}$ slurry was added to achieve the target $50 \mathrm{~g}$ of $\mathrm{CaO}$ ( $\mathrm{kg}$ of stover $\mathrm{DM})^{-1}$ and $500 \mathrm{~g}$ of $\mathrm{H}_{2} \mathrm{O}$ ( $\mathrm{kg}$ of stover $\left.\mathrm{DM}\right)^{-1}$. Following thorough mixing, the treated stover was packed into a plastic silage bag using specialized mechanical equipment sized to fill and pack a $2.4 \mathrm{~m}$ in diameter silage bag (Ag-Bagger, Ag-Bag, St. Nazianz, WI) and stored anaerobically for at least $60 \mathrm{~d}$, which is more than the required $7 \mathrm{~d}$ for effective treatment at ambient temperature and pressure (Shreck, 2013).

\section{Cows and Diets}

Eight ruminally cannulated lactating Holstein cows, averaging (mean $\pm \mathrm{SD}$ ) $108 \pm 58$ DIM, $686 \pm 103 \mathrm{~kg}$ of BW, and $35.3 \pm 4.6 \mathrm{~kg}$ of milk. ${ }^{-1}$, were randomly assigned to a replicated $4 \times 4$ Latin square. Treatment periods were $21 \mathrm{~d}$, with $14 \mathrm{~d}$ for acclimation and the final $7 \mathrm{~d}$ of the period were used for sample and data collection. Treatments were linear increases in the partial replacement of dry corn grain with $\mathrm{CaO}$ treated corn stover in the diet. The 4 treatments (Table 1 ) were TS0 (0\% stover, and $18.6 \%$ grain), TS4 (4.4\% stover and $14.6 \%$ grain), TS8 (8.6\% stover and $10.7 \%$ grain), and TS12 (12.9\% stover and $6.7 \%$ grain). Ground limestone was added to the TS0, TS4, and TS8 diets to equalize dietary $\mathrm{Ca}$ concentrations across all treatments. The diet composition presented in Table 1 is that recorded from actual weighing of ingredients in the feeding system.

Diets were fed once daily at $0700 \mathrm{~h}$ as a TMR to the cows individually on an ad libitum basis. Milk production, feed offered, and orts were recorded daily throughout the experiment. All cows used in this study were maintained under protocols approved by the University of Wisconsin Institutional Animal Care and Use Committee. The cows were housed in a tie-stall barn bedded with rubber mattresses and chopped straw at the USDA-ARS US Dairy Forage Research Center Farm in Prairie du Sac, Wisconsin.

\section{Sample Collection}

Cows were milked twice daily at 0400 and $1600 \mathrm{~h}$ in a milking parlor. Milk was sampled for compositional analysis at both milkings on d 17, 18, and 19 of each period. Milk samples were analyzed for composition by AgSource Milk Analysis Laboratory (Menomonie, WI) using mid-infrared analysis with a Foss FT6000 instrument (method 972.12; AOAC, 1990). Milk energy density (as $\mathrm{NE}_{\mathrm{L}} \mathrm{Mcal} \cdot \mathrm{kg}^{-1}$ ), was calculated from NRC equations (equations 2-15, NRC, 2001). Equivalent wet volume fecal samples were collected on d 17 through 19 of each period to represent sampling every $4 \mathrm{~h}$ over a 24-h cycle. The sampling commenced at $0300 \mathrm{~h}$ on d 17 and continued at $1500 \mathrm{~h}(\mathrm{~d} 17), 0700 \mathrm{~h}(18 \mathrm{~d}), 1900 \mathrm{~h}$ $(18 \mathrm{~d}), 1100 \mathrm{~h}(19 \mathrm{~d})$, and $2300 \mathrm{~h}$ (19 d). Fecal samples were dried at $55^{\circ} \mathrm{C}$ and then composited by cow within period. At the $0700 \mathrm{~h}$ sampling (d 18), $\mathrm{pH}$ was taken on fecal samples before drying, using an electronic $\mathrm{pH}$ meter (315i; WTW Wissenschaftlich-Technische Werkstätten GmbH, Weilheim, Germany).

Rumen fluid was sampled below the ruminal mat from the ventral area of the rumen, on d 16 every hour 
Table 1. Measured feed and chemical compositions of diets

\begin{tabular}{|c|c|c|c|c|}
\hline \multirow[b]{2}{*}{ Item } & \multicolumn{4}{|c|}{ Treatment $^{1}$} \\
\hline & TS0 & TS4 & TS8 & TS12 \\
\hline \multicolumn{5}{|l|}{ Feedstuff, \% of DM } \\
\hline Corn silage & 34.4 & 33.6 & 35.0 & 33.9 \\
\hline Alfalfa silage & 20.6 & 20.7 & 20.2 & 20.3 \\
\hline $\mathrm{CaO}$-treated stover & 0.0 & 4.4 & 8.6 & 13.0 \\
\hline Dry-ground corn grain & 18.5 & 14.7 & 10.4 & 6.5 \\
\hline Distillers grain with solubles & 9.3 & 9.2 & 9.0 & 9.0 \\
\hline Soybean meal & 10.2 & 10.8 & 10.7 & 11.3 \\
\hline Soyhulls & 4.0 & 3.7 & 3.7 & 3.7 \\
\hline Vitamin and mineral premix ${ }^{2}$ & 2.1 & 2.4 & 2.0 & 2.3 \\
\hline Limestone & 0.9 & 0.5 & 0.2 & 0.0 \\
\hline \multicolumn{5}{|l|}{ Composition, $\%$ of DM } \\
\hline $\mathrm{OM}$ & 92.6 & 92.1 & 92.1 & 91.5 \\
\hline $\mathrm{CP}$ & 16.7 & 16.7 & 16.4 & 16.4 \\
\hline $\mathrm{NDF}$ & 28.8 & 30.4 & 32.8 & 34.7 \\
\hline $\mathrm{ADF}$ & 17.3 & 18.9 & 20.7 & 22.3 \\
\hline ADL & 2.0 & 2.2 & 2.3 & 2.5 \\
\hline $\operatorname{pdNDF}^{3}$ & 20.0 & 21.2 & 22.6 & 23.9 \\
\hline Starch & 26.9 & 23.9 & 21.4 & 18.3 \\
\hline $\mathrm{GMPS},{ }^{4} \mathrm{~mm}$ & 2.3 & 2.3 & 2.3 & 2.4 \\
\hline \multicolumn{5}{|c|}{$\begin{array}{l}{ }^{1} \text { TS0 diet }=0 \% \text { stover and } 18.6 \% \text { grain; TS } 4=4.4 \% \text { stover and } 14.6 \% \text { grain; TS } 8=8.6 \% \text { stover and } 10.7 \% \\
\text { grain; and TS12 }=12.9 \% \text { stover and } 6.7 \% \text { grain. }\end{array}$} \\
\hline \multicolumn{5}{|c|}{$\begin{array}{l}{ }^{2} \text { Contained } 39 \% \text { calcium carbonate, } 11 \% \text { salt, } 4.5 \% \mathrm{Mg}, 0.4 \% \mathrm{P}, 0.9 \% \mathrm{~S}, 14 \mathrm{mg} / \mathrm{kg} \text { of Se, } 485 \mathrm{mg} / \mathrm{kg} \text { of monen- } \\
\text { sin, } 282 \mathrm{IU} \text { of vitamin A } \cdot \mathrm{g}^{-1} \text {, } 55 \mathrm{IU} \text { of vitamin } \mathrm{D}_{3} \cdot \mathrm{g}^{-1}, 1.3 \mathrm{IU} \text { of vitamin } \mathrm{E} \cdot \mathrm{g}^{-1} \text {. } \\
{ }^{3} \text { Potentially digestible NDF. }\end{array}$} \\
\hline
\end{tabular}

commencing immediately before feed was offered (0700 h), until $6 \mathrm{~h}$ postfeeding. Rumen fluid was analyzed for $\mathrm{pH}$, strained through 4 layers of cheesecloth, and aliquots for organic acid analysis were immediately frozen at $-20^{\circ} \mathrm{C}$. Rumen digesta were manually evacuated from each cow via the ruminal cannula at 0900 $\mathrm{h}$ on d 21, $2 \mathrm{~h}$ postfeeding. During evacuation, a $10 \%$ aliquot was separated for sampling. From this aliquot, three 1-kg sub-samples were taken for determination of $\mathrm{DM}$ at $46^{\circ} \mathrm{C}$ and composition. Total digesta wet matter (WM) was measured and the composition of digesta samples (DM, OM, and NDF) was determined on the sub-samples, from which ruminal pool sizes of composition were calculated. Ruminal component turnover rate was calculated as the rate of nutrient intake as a fraction of the nutrient pool size (Taylor and Allen, 2005). Results from one animal in one period were lost when the cow tipped over the bucket of digesta contents and some of the digesta contents were lost.

\section{Laboratory Analysis and Calculations}

Forages and TMR samples were collected daily and composited by sampling period. Concentrates were collected on d 20 of each period. Orts for individual animals were sampled on d 17, 18, and 19 of each period, and each animal's daily nutrient intake for the period was corrected for the nutrient content of the orts. All samples were frozen at $-20^{\circ} \mathrm{C}$ until analysis. Samples were dried in duplicate for $24 \mathrm{~h}$ at $55^{\circ} \mathrm{C}$ in a forcedair oven. One sub-sample was then used to determine DM content, by subsequent drying at $105^{\circ} \mathrm{C}$ for $48 \mathrm{~h}$; the remainder of the $55^{\circ} \mathrm{C}$-dried sample was ground for chemical analysis. Following the $105^{\circ} \mathrm{C}$ drying, that subsample was used for particle size determination. Dried samples for constituent analysis were ground to pass a 1-mm screen using a Wiley mill (Arthur H. Thomas, Philadelphia, PA). All samples were analyzed for DM, OM (method 942.05; AOAC International, 2006), CP (method 990.03; AOAC International, 2006), NDF using $\alpha$-amylase and sodium sulfite in filter bags (Ferreira and Mertens, 2007), ADF (method 978.10; AOAC International, 2006), ADL (method 978.10; AOAC International, 2006), and starch using the sodium acetate buffer method (Hall, 2009). Starch analysis was performed on sub-samples that were ground through a 1-mm screen of an abrasion mill (Udy Corp., Fort Collins, CO). Indigestible NDF (iNDF) was determined by 288 -h in situ incubation in bags with a pore size of $25 \mu \mathrm{m}$, as detailed by Huhtanen et al. (1994). Potentially digestible NDF is calculated as total NDF less iNDF. The TMR compositions reported in Table 1 were calculated by multiplying the proportion of a feed in the diet DM by its compositional analysis and summing the results for all feeds for each diet in each sampling period. 
Total-tract digestibility was calculated using iNDF as the internal marker. The NDF kinetics were calculated using a 2-pool (pdNDF and iNDF) model for fractional rates of passage and digestion in the reticulorumen (Matis and Wehrly, 1979; Pond et al., 1988), and using an assumption of $10 \%$ of NDF digested postruminally (Lopes et al., 2015). Ruminal rate of digestion for pdNDF equals the potentially digestible NDF digestibility multiplied by the rumen clearance rate (Matis and Wehrly, 1979; Pond et al., 1988).

For organic acid analysis, rumen fluid was thawed at room temperature (approximately $23^{\circ} \mathrm{C}$ ) and centrifuged at $12,000 \times g$ for $10 \mathrm{~min}$. Organic acid concentrations in the supernatant were analyzed by HPLC (Weimer et al., 1991). Branched-chain VFA were the sum of isovalerate, isobutyrate, and 2-methyl butyrate. Ruminal pool size in moles was determined for each cow in each period, as the 2 -h postfeeding concentrations multiplied by the ruminal liquid content $2 \mathrm{~h}$ postfeeding. Ruminal liquid was assumed to have a density of $1 \mathrm{~g} \cdot \mathrm{mL}^{-1}$.

Particle size of dried feeds and TMR samples were determined with dry sieving. Dried samples were shaken for 10 min in a Ro-Tap test sieve shaker (W. S. Tyler Industrial Group, Mentor, OH.). The shaker was equipped with $6.7 \mathrm{~mm}, \# 4$, \#6, \#8, \#12, \#16, \#20, $\# 30$, and \#50 sieves for TMR and forages. Dry ground corn, soy hulls, and soybean meal were separated with sieves $\# 4, \# 6, \# 8, \# 12, \# 16, \# 20, \# 30$, \#50, and \#140. The geometric mean particle size was calculated using ASABE S424.1 (ASABE, 2007).

\section{Behavior}

Standing, laying, eating, and ruminating behaviors were visually assessed and recorded every $10 \mathrm{~min}$ over $24 \mathrm{~h}$ on $\mathrm{d} 20$ in each period. A meal event was defined as 1 or more eating observation preceded by an observation where eating was not observed. Standing, laying, and rumination events were defined as at least 2 consecutive observations preceded by an observation where the behavior was not observed. Total time for each behavior was calculated by the sum of the observations multiplied by the 10-min interval between observations. Time spent chewing was calculated as the sum of rumination and eating times. Individual times spent eating and ruminating per unit of intake were calculated using the sampling period average DMI for each cow.

\section{Statistical Analyses}

Variables in the statistical analysis were $\mathrm{Y}=$ the dependent variable, $\mu=$ overall mean, $S_{i}=$ fixed effect of square, $\mathrm{P}_{\mathrm{j}}=$ fixed effect of sampling period, $\mathrm{C}_{\mathrm{k}(\mathrm{i})}=$ the random effect of cow $\mathrm{k}$ (within square $\mathrm{i}$ ), $\mathrm{T}_{1}=$ fixed effect of treatment, $\mathrm{H}_{\mathrm{m}}$ = sampling hour for ruminal measures, and $\varepsilon=$ the random residual error. In the statistical models, interaction terms are represented by the combinations of the variable letters. Time of low ruminal $\mathrm{pH}$ was calculated as the number of hourly ruminal $\mathrm{pH}$ measurements that were less than 5.8. Intake, lactational performance, digestibility, behavior, lowest detected ruminal $\mathrm{pH}$, time of low ruminal $\mathrm{pH}$, and ruminal pool size data were analyzed using the MIXED model procedure of SAS (version 9.2, SAS Institute Inc., Cary, NC) for a Latin square design. With variables defined as previously described, the model used was

$$
\mathrm{Y}_{\mathrm{ijkl}}=\mu+\mathrm{T}_{\mathrm{l}}+\mathrm{P}_{\mathrm{j}}+\mathrm{C}_{\mathrm{k}(\mathrm{i})}+\mathrm{S}_{\mathrm{i}}+\mathrm{TP}_{\mathrm{lj}}+\mathrm{TS}_{\mathrm{li}}+\varepsilon_{\mathrm{ijk} \mathrm{l}} .
$$

The interactions $\mathrm{TP}_{\mathrm{lj}}$ and $\mathrm{TS}_{\mathrm{li}}$ were removed from the model if $P>0.25$.

Ruminal organic acid proportions and $\mathrm{pH}$ time course data from the 7 hourly samplings were analyzed as repeated measures in time with the model:

$$
\begin{aligned}
\mathrm{Y}_{\mathrm{ijklm}}=\mu & +\mathrm{T}_{1}+\mathrm{P}_{\mathrm{j}}+\mathrm{C}_{\mathrm{k}(\mathrm{i})}\left(\mathrm{P}_{\mathrm{j}} \mathrm{T}_{\mathrm{l}}\right)+\mathrm{S}_{\mathrm{i}}+\mathrm{H}_{\mathrm{m}}+\mathrm{TP}_{\mathrm{lj}} \\
& +\mathrm{TS}_{\mathrm{li}}+\mathrm{TH}_{\mathrm{lm}}+\mathrm{PH}_{\mathrm{jm}}+\varepsilon_{\mathrm{ijklm}} .
\end{aligned}
$$

Covariance structures were selected for each dependent variable on the basis of the smallest Akaike information criterion value.

Linear and quadratic responses to treatment were evaluated using orthogonal contrasts. Cubic responses were also evaluated but were omitted because none were significant. Significance was declared at $P \leq 0.05$ and a tendency at $0.05<P \leq 0.10$. All reported values are least squares means.

\section{RESULTS AND DISCUSSION}

\section{Feed Characteristics}

Diet and ingredient compositions are presented in Tables 1 and 2, respectively. The diets were composed primarily of corn silage ( $34 \%$ of ration DM), alfalfa silage ( $20 \%$ of ration DM), concentrates, and corn stover in treatment diets. The post-CaO-treatment corn stover contained $43.2 \%$ pdNDF, $3.4 \% \mathrm{CP}$, and $15.7 \%$ ash. Dietary NDF concentration increased from 28.8 to $34.7 \%$ with increasing levels of treated stover, and pdNDF increased from 20.0 to $23.9 \%$. As corn was replaced, starch in the diet decreased from 26.9 to $18.3 \%$, resulting in a higher fiber, lower starch diet. 
Table 2. Characterization of dietary ingredients

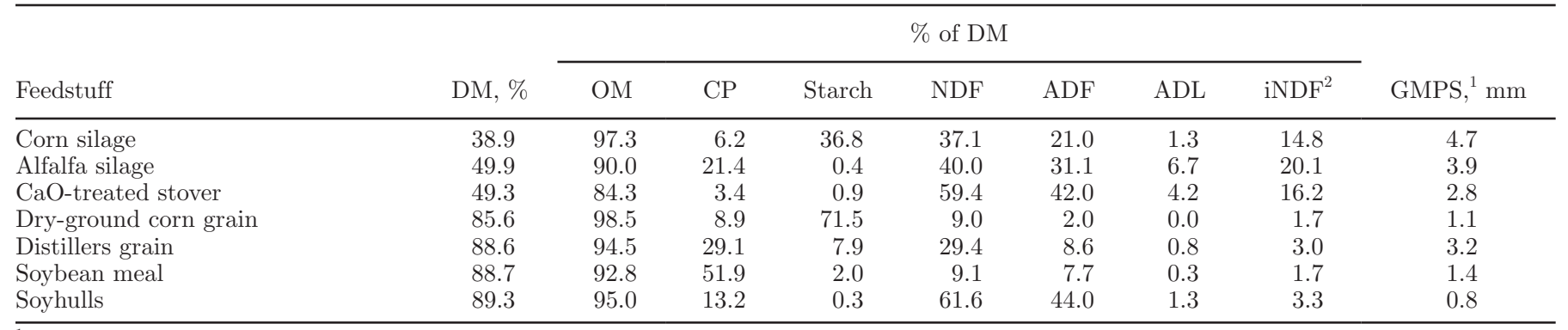

${ }^{1}$ Geometric mean particle size.

${ }^{2}$ Indigestible NDF, $288 \mathrm{~h}$ in situ ruminal incubation.

\section{Performance}

Dry matter intake decreased linearly $(P<0.001)$ and NDF intake increased linearly $(P=0.01)$ with increasing levels of stover for grain replacement (Table 3). This is similar to the findings of others (Cameron et al., 1991; Haddad et al., 1998), where DMI decreased when treated fiber was added to the diet. However, when treated fiber replaced the same type of untreated fiber in the diet, DMI and NDF intakes both increased (Jackson, 1977; Canale et al., 1988). Improving the digestibility of NDF in the ration has a positive effect on intake, whereas increasing the total NDF content of the ration can have a negative effect on intake (Mertens, 1987). In the present study, all production measurements, with the exception of milk protein concentration, declined linearly $(P<0.05$, Table 3$)$ and concur- rently with decreasing DMI as stover levels increased in the diet. Feed efficiency $\left(\mathrm{NE}_{\mathrm{L}}\right.$ Mcal of milk $\left.\mathrm{DMI}^{-1}\right)$ was unaffected by treatment (Table 3 ).

\section{Rumen Measurements and Organic Acids}

The lowest detected $\mathrm{pH}$ increased linearly $(P=0.02)$ with increasing stover inclusion, whereas the amount of time rumen $\mathrm{pH}$ was less than 5.8 declined linearly $(P=0.02$, Table 4; Figure 1$)$. Work done by Cameron et al. $(1990,1991)$ showed increases in mean rumen $\mathrm{pH}$ with diets into which increasing levels of alkaline hydrogen peroxide-treated wheat and oat straw were substituted, to achieve a similar high-fiber, low-starch diet. However, this effect is not uniform. In the present study, mean rumen $\mathrm{pH}$ (Table 4) was not affected by treatment $(P \geq 0.35)$. Similarly, Haddad et al. (1998)

Table 3. Daily feed intake, milk production, milk composition, and production efficiency

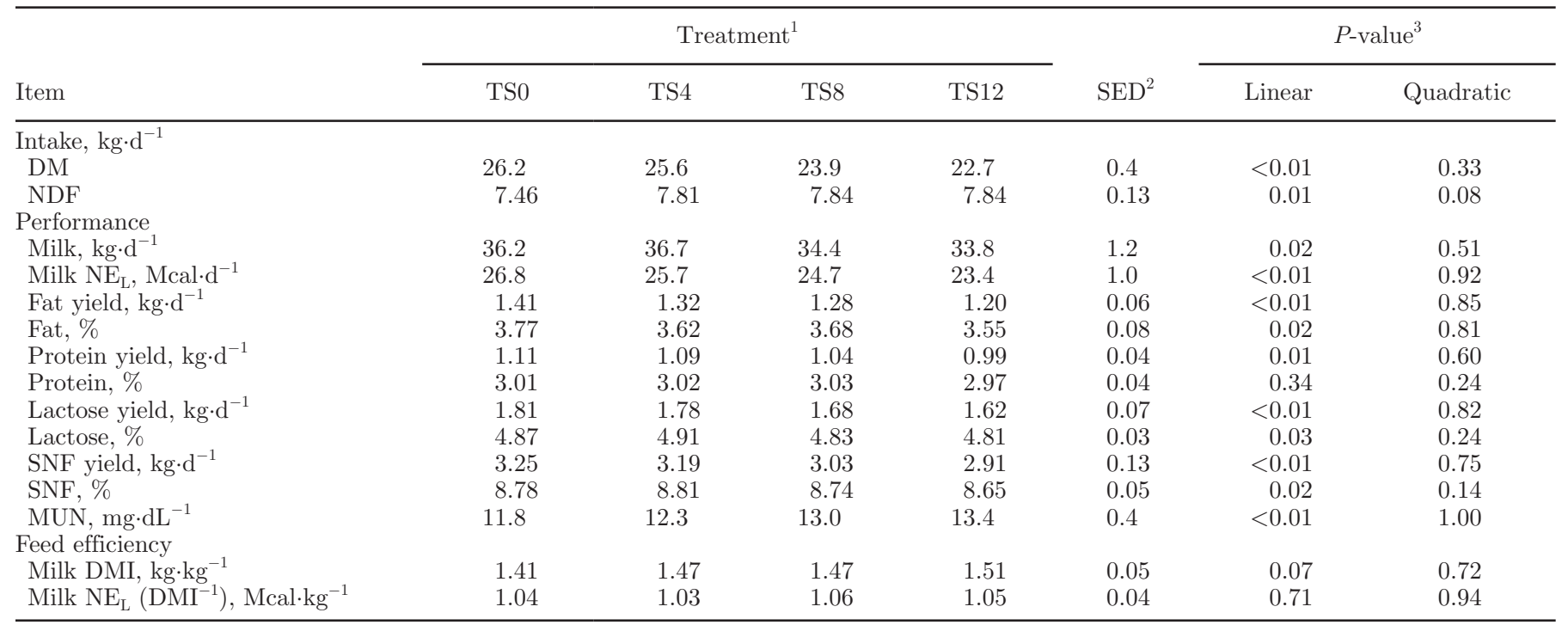

${ }^{1}$ TS0 diet $=0 \%$ stover and $18.6 \%$ grain; TS4 $=4.4 \%$ stover and $14.6 \%$ grain; TS $8=8.6 \%$ stover and $10.7 \%$ grain; and TS12 $=12.9 \%$ stover and $6.7 \%$ grain.

${ }^{2} \mathrm{SED}=$ standard error of the difference.

${ }^{3}$ Main effect, linear, and quadratic effects of diet. 
Table 4. Effects of treated stover substitution for corn grain on ruminal and fecal $\mathrm{pH}$, and ruminal organic acids

\begin{tabular}{|c|c|c|c|c|c|c|c|}
\hline Item & \multicolumn{4}{|c|}{ Treatment $^{1}$} & $\mathrm{SED}^{2}$ & \multicolumn{2}{|c|}{$P$-value ${ }^{3}$} \\
\hline Mean fecal pH & 6.33 & 6.39 & 6.45 & 6.47 & 0.06 & 0.02 & 0.68 \\
\hline \multicolumn{8}{|l|}{ Rumen $\mathrm{pH}$} \\
\hline Lowest detected & 5.83 & 5.83 & 5.93 & 5.94 & 0.05 & 0.02 & 0.84 \\
\hline Mean ruminal pH & 6.09 & 6.10 & 6.14 & 6.15 & 0.07 & 0.35 & 0.94 \\
\hline Time points below 5.8 & 0.88 & 1.00 & 0.25 & 0.13 & 0.38 & 0.02 & 0.65 \\
\hline Propionate & 2.59 & 2.81 & 2.73 & 2.64 & 0.24 & 0.90 & 0.35 \\
\hline Butyrate & 1.5 & 1.6 & 1.5 & 1.4 & 0.1 & 0.52 & 0.28 \\
\hline Valerate & 0.21 & 0.23 & 0.22 & 0.21 & 0.02 & 0.87 & 0.22 \\
\hline $\mathrm{BCVFA}^{4}$ & 0.32 & 0.34 & 0.32 & 0.29 & 0.03 & 0.17 & 0.13 \\
\hline Total organic acids & 12.2 & 13.1 & 13.0 & 12.8 & 0.9 & 0.59 & 0.37 \\
\hline Total organic acids, m $M$ & 153 & 153 & 150 & 154 & 6 & 0.96 & 0.65 \\
\hline \multicolumn{8}{|c|}{ Ruminal organic acids, molar percentages } \\
\hline
\end{tabular}

${ }^{1}$ TS0 diet $=0 \%$ stover and $18.6 \%$ grain; TS4 $=4.4 \%$ stover and $14.6 \%$ grain; TS $8=8.6 \%$ stover and $10.7 \%$ grain; and TS $12=12.9 \%$ stover and $6.7 \%$ grain.

${ }^{2} \mathrm{SED}=$ standard error of the difference.

${ }^{3}$ Main effect, linear, and quadratic effects of diet.

${ }^{4}$ Branched-chain volatile fatty acids.

${ }^{5} \mathrm{~A}: \mathrm{P}=$ acetate to propionate ratio.

found that mean ruminal $\mathrm{pH}$ was unaffected when treated wheat straw replaced untreated wheat straw in a high-forage diet (33.4\% NDF), although ruminal $\mathrm{pH}$ for the control treatment was already high at 6.4. Fecal $\mathrm{pH}$ increased linearly $(P=0.02)$ with stover inclusion. A possible cause for this is that lower starch in the diet and reduced intakes (starch intakes were approximately $7.0,6.1,5.1$, and $4.2 \mathrm{~kg}$ of starch per day for TS0, TS4, TS8, and TS12, respectively) likely resulted in reduced amounts of starch reaching and fermenting in the large intestine. The change in fecal $\mathrm{pH}$ was similar to results reported by Canale et al. (1988), who observed an increase from 6.23 to 6.34 .

The mole amounts of acetate, propionate, butyrate, valerate, and branched-chain VFA determined on the evacuated rumen contents at $2 \mathrm{~h}$ postfeeding were unaffected by treatment $(P \geq 0.17$, Table 4$)$. Total rumen organic acid concentration was unaffected by treatment $(P=0.90)$. The molar proportions of acetate and propionate were not affected $(P \geq 0.19)$, and the molar proportions of butyrate and valerate decreased linearly with stover inclusion $(P<0.02, P<0.01$, respectively). The ratio of acetate to propionate ranged from 3.2 to 3.3 and was not affected by treatment $(P=0.94)$. In a similar experiment with inclusion of treated stover and reduced corn grain, Haddad et al. (1998) also found no effect of treatment on acetate or propionate concentrations. Results in the literature regarding the effects of substituting alkali-treated forage on ruminal acetate:propionate ratios are mixed, with reports of no effect (Latham et al., 1979; Canale et al., 1988; Cameron et al., 1990; Haddad et al., 1998), a decrease (Jackson, 1977), or an increase (Brown et al., 1990).

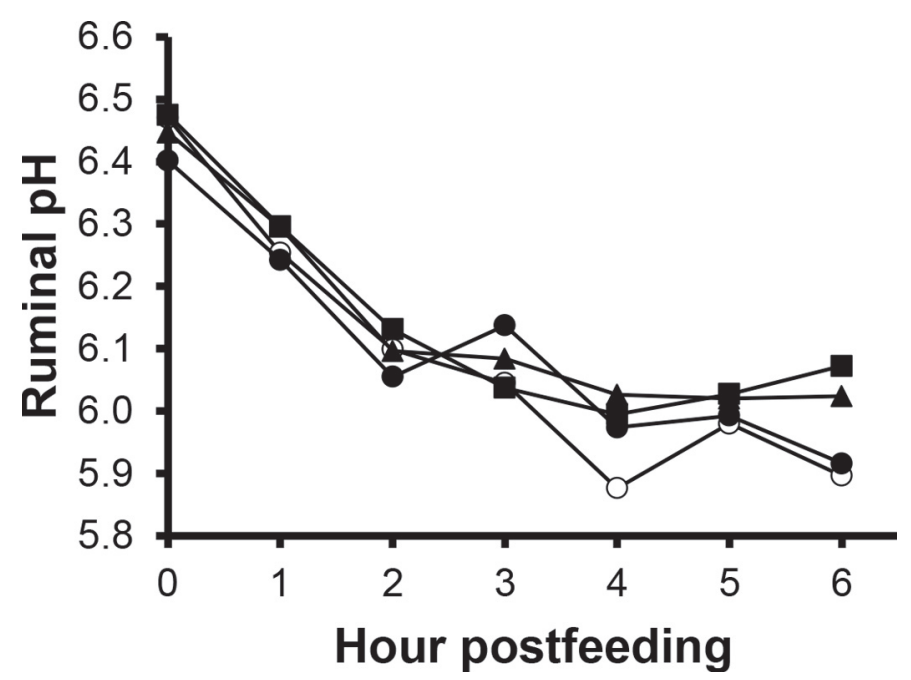

Figure 1. Ruminal $\mathrm{pH}$ measured through $6 \mathrm{~h}$ postfeeding. Dietary treatments: $\operatorname{TS} 0=0$, TS4 $=\boldsymbol{\bullet}$, TS $8=\boldsymbol{\Delta}$, and TS12 $=\mathbf{\square}$, where TSX $=$ calcium oxide-treated corn stover as X percentage of diet DM. $P$-values: time, $P<0.01$; diet, $P=0.89$; time $\times \operatorname{diet,~} P=0.24$. Standard error of the difference $=0.096$. 
Table 5. Effects of treated stover substitution for corn grain on rumen digesta mass at $2 \mathrm{~h}$ postfeeding

\begin{tabular}{lrrrrrrrr}
\hline & \multicolumn{4}{c}{ Treatment $^{1}$} & & \multicolumn{2}{c}{$P$-value } \\
\cline { 2 - 4 } $\begin{array}{l}\text { Digesta } \\
\text { contents, kg }\end{array}$ & TS0 & TS4 & TS8 & TS12 & SED $^{2}$ & Linear & Quadratic \\
\hline WM $^{4}$ & 92.5 & 94.3 & 92.8 & 92.6 & 4.0 & 0.91 & 0.71 \\
Liquid $^{5}$ & 78.9 & 79.5 & 78.7 & 78.1 & 3.4 & 0.75 & 0.79 \\
DM & 13.7 & 14.8 & 14.3 & 14.5 & 0.6 & 0.21 & 0.28 \\
OM & 12.2 & 12.5 & 12.6 & 12.6 & 0.4 & 0.28 & 0.57 \\
NDF & 7.3 & 7.6 & 7.6 & 7.8 & 0.3 & 0.09 & 0.98 \\
iNDF $^{6}$ & 4.3 & 4.5 & 4.3 & 4.5 & 0.1 & 0.38 & 0.80 \\
pdNDF $^{7}$ & 3.0 & 3.1 & 3.3 & 3.3 & 0.2 & 0.09 & 0.73 \\
\hline
\end{tabular}

${ }^{1}$ TS0 diet $=0 \%$ stover and $18.6 \%$ grain; TS4 $=4.4 \%$ stover and $14.6 \%$ grain; TS $8=8.6 \%$ stover and $10.7 \%$ grain; and TS12 $=12.9 \%$ stover and $6.7 \%$ grain.

${ }^{2} \mathrm{SED}=$ standard error of the difference.

${ }^{3}$ Main effect, linear, and quadratic effects of diet.

${ }^{4} \mathrm{WM}=$ wet matter.

${ }^{5}$ Liquid is difference of WM and DM on drying.

${ }^{6} \mathrm{iNDF}=$ indigestible NDF.

${ }^{7}$ pdNDF $=$ potentially digestible NDF.

\section{Rumen Kinetics (and Digesta)}

The DM, OM, and WM ruminal pool size, as measured by rumen evacuation, were not affected by treatment $(P>0.20$, Table 5$)$. The NDF and pdNDF pool size tended to increase $(P=0.09)$ with stover inclusion. These pool size increases matched the magnitude of the increases in NDF and pdNDF intake, resulting in a pdNDF digesta residence time that was unaffected by treated stover inclusion. The DM ruminal residence time decreased linearly $(P<0.001)$ with increasing levels of stover inclusion (Table 6). The iNDF pool size was unaffected by stover inclusion $(P=0.40)$, which was caused by a linear increase in both rate of intake $(P<0.01)$ and rate of passage $(P=0.04)$. Ruminal pool size being similar for iNDF and pdNDF across treatments suggests that DMI in cows on all diets were constrained by ruminal fill.

Stover replacement for grain did not affect pdNDF digestion rate, which ranged from 4.66 to $5.00 \% \mathrm{~h}^{-1}$. The apparent numeric decline in the passage rate of the pdNDF fraction with increasing stover inclusion was not significant $(P \geq 0.16)$. These results demonstrate that as treated stover comprised an increasingly larger fraction of the diet, there was a decrease in DMI, a decrease in starch intake, an increase in lowest detected ruminal $\mathrm{pH}$, a decline in the hours of ruminal $\mathrm{pH}$ below 5.8 , and a numeric decrease in passage of pdNDF, all leading to an end result of the total-tract NDF digestibility of the TMR being similar among all treatments. However, rumen capacity was likely reached at or near the control treatment, and the increase in NDF in the

Table 6. Effects of treated stover substitution for corn grain on rumen kinetics

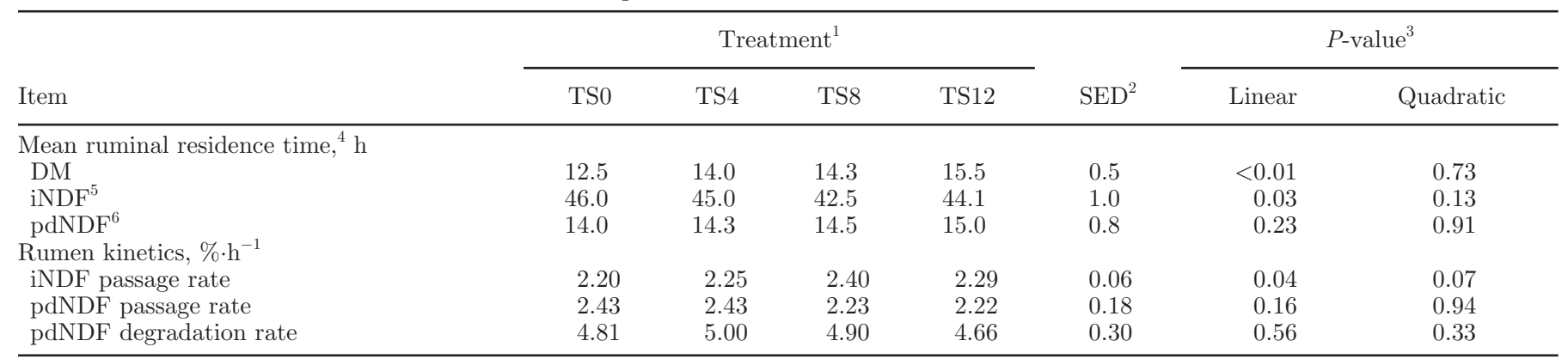

${ }^{1}$ TS0 diet $=0 \%$ stover and $18.6 \%$ grain; TS $4=4.4 \%$ stover and $14.6 \%$ grain; TS $8=8.6 \%$ stover and $10.7 \%$ grain; and TS12 $=12.9 \%$ stover and $6.7 \%$ grain.

${ }^{2} \mathrm{SED}=$ standard error of the difference.

${ }^{3}$ Main effect, linear, and quadratic effects of diet.

${ }^{4}$ Mean ruminal residence time $=($ rumen digesta nutrient mass $) \cdot(\text { nutrient intake, mass per hour })^{-1}$.

${ }^{5} \mathrm{iNDF}=$ indigestible NDF.

${ }^{6} \mathrm{pdNDF}=$ potentially digestible NDF. 
Table 7. Effects of treated stover substitution for corn grain on apparent total-tract digestibilities

\begin{tabular}{|c|c|c|c|c|c|c|c|}
\hline Item & \multicolumn{4}{|c|}{ Treatment $^{1}$} & $\mathrm{SED}^{2}$ & \multicolumn{2}{|c|}{$P$-value ${ }^{3}$} \\
\hline $\mathrm{DM}$ & 71.4 & 70.7 & 70.6 & 67.3 & 0.9 & $<0.01$ & 0.67 \\
\hline $\mathrm{OM}$ & 74.3 & 72.8 & 71.4 & 69.3 & 0.8 & $<0.01$ & 0.66 \\
\hline NDF & 51.5 & 52.1 & 52.4 & 51.5 & 1.0 & 0.91 & 0.30 \\
\hline $\mathrm{pdNDF}^{4}$ & 74.2 & 75.3 & 76.5 & 75.3 & 1.4 & 0.36 & 0.29 \\
\hline pdNDF intake, $\mathrm{kg}$ & 5.18 & 5.40 & 5.38 & 5.37 & 0.09 & 0.08 & 0.11 \\
\hline NDF digested, kg & 3.82 & 4.05 & 4.09 & 4.07 & 0.07 & $<0.01$ & 0.03 \\
\hline DM digested, kg & 19.0 & 18.1 & 16.6 & 15.2 & 0.3 & $<0.01$ & 0.38 \\
\hline
\end{tabular}

${ }^{1}$ TS0 diet $=0 \%$ stover and $18.6 \%$ grain; TS4 $=4.4 \%$ stover and $14.6 \%$ grain; TS $8=8.6 \%$ stover and $10.7 \%$ grain; and TS12 $=12.9 \%$ stover and $6.7 \%$ grain.

${ }^{2} \mathrm{SED}=$ standard error of the difference.

${ }^{3}$ Main effect, linear, and quadratic effects of diet.

${ }^{4} \mathrm{pdNDF}=$ potentially digestible NDF.

${ }^{5} \mathrm{iNDF}=$ indigestible NDF.

diets from addition of $\mathrm{CaO}$-treated corn stover resulted in lower DMI due to rumen fill.

\section{Apparent Total-Tract Digestibility}

Apparent total-tract DM, OM, and OM less indigestible fiber digestibility measurements all decreased linearly (Table $7, P<0.01$ ) when corn grain was replaced with treated corn stover. This was expected because corn is generally more digestible than corn stover. Cameron et al. (1990) also demonstrated that treated straw as a replacement for alfalfa haylage and corn silage reduced DM and OM digestibility. Total-tract digestibility of NDF and pdNDF was not affected, as corn stover comprised increasing levels of dietary NDF. This implies that the digestibility of the treated corn stover is similar to the NDF in the control diet, derived primarily from alfalfa haylage and whole plant corn silage. Although it has been shown that alkali treatments can improve fiber digestibility, the maintenance of NDFD across diets with increasing stover inclusion may not strictly relate to inherent digestion properties of the treated stover. Some portion of this response may be due to effects on ruminal $\mathrm{pH}$ and passage. The increases in lowest detected rumen $\mathrm{pH}$ and decrease in time that the $\mathrm{pH}$ was below 5.8 (Table 4) could have positive effects on ruminal NDF digestion. Although they were not significant, the numeric declines with increasing stover inclusion for pdNDF passage rate, and numeric increase of pdNDF mean ruminal residence time (Table 6 ) that coincided with a significant decline in DMI (Table 3) are suggestive of increased ruminal retention time, which could also affect total-tract fiber digestibility. Further work with more animals and multiple rumen evacuation times would determine the extent to which passage or retention influenced the results.

Total daily amount of DM digested decreased linearly $(P<0.001)$ from 19.0 to $15.2 \mathrm{~kg}$. Dividing the digested DM into NDF and non-NDF fractions, the NDF digested increased linearly $(P<0.01)$ from 3.82 to $4.07 \mathrm{~kg}$ with the treated stover replacement, whereas the total-tract non-NDF DM digested declined linearly $(P<0.001)$ from 15.2 to $11.2 \mathrm{~kg}$ (data not shown). Whereas stover substitution increased NDF concentration and NDF digested, the increased digested NDF mass is an order of magnitude less than the decreased mass of non-NDF DM digested.

\section{Behavior}

Time and time per kilogram of NDF intake spent standing, lying, eating, ruminating, and total chewing time was not affected by treatment (Table $8, P \geq$ $0.38)$. No effect was found of treatment on the number of eating and rumination events (Table $8, P \geq 0.22$ ). As DMI decreased with stover inclusion, time spent eating and ruminating increased linearly per kilogram of DMI $(P<0.01)$. Oba and Allen $(2000)$ conducted a study evaluating level of NDF dietary concentration and altered digestibility and also found no effect on the number of eating events and meal duration, but observed increases in time spent eating and ruminating per kilogram of DMI for animals with physical fill limitations and lower DMI. Total time chewing was not affected by treatment and ranged from 771 to 806 $\min \cdot \mathrm{d}^{-1}$. The chewing time per unit of NDF was also not affected. 
Table 8. Effects of treated stover substitution for corn grain on daily cow behavior

\begin{tabular}{|c|c|c|c|c|c|c|c|}
\hline Item & \multicolumn{4}{|c|}{ Treatment $^{1}$} & $\mathrm{SED}^{2}$ & \multicolumn{2}{|c|}{$P$-value ${ }^{3}$} \\
\hline \multicolumn{8}{|l|}{ Standing } \\
\hline Events, $\mathrm{d}^{-1}$ & 8.4 & 8.4 & 7.8 & 6.9 & 0.7 & 0.03 & 0.37 \\
\hline \multicolumn{8}{|l|}{ Laying } \\
\hline Time, $\min \cdot \mathrm{d}^{-1}$ & 861 & 833 & 836 & 879 & 38 & 0.65 & 0.20 \\
\hline Time, min $\cdot \mathrm{kg}$ of $\mathrm{DMI}^{-1}$ & 19.3 & 20.8 & 22.1 & 22.4 & 0.9 & $<0.01$ & 0.41 \\
\hline Time, min $\cdot \mathrm{kg}$ of NDF intake ${ }^{-1}$ & 67.9 & 67.8 & 67.3 & 65.1 & 2.9 & 0.38 & 0.64 \\
\hline Periods, $\mathrm{d}^{-1}$ & 12.9 & 13.8 & 13.0 & 12.3 & 0.7 & 0.24 & 0.11 \\
\hline Duration of period, min & 38.7 & 39.1 & 40.2 & 42.3 & 2.5 & 0.15 & 0.62 \\
\hline \multicolumn{8}{|l|}{ Eating } \\
\hline Time, $\min \cdot \mathrm{d}^{-1}$ & 274 & 289 & 286 & 289 & 18 & 0.46 & 0.63 \\
\hline Time, $\min \cdot \mathrm{d}^{-1}$ & 771 & 806 & 803 & 790 & 29 & 0.58 & 0.27 \\
\hline Time, min $\cdot \mathrm{kg}$ of $\mathrm{DMI}^{-1}$ & 29.8 & 32.3 & 34.2 & 35.4 & 1.2 & $<0.01$ & 0.47 \\
\hline Time, min $\cdot \mathrm{kg}$ of NDF intake ${ }^{-1}$ & 105 & 106 & 104 & 103 & 4 & 0.46 & 0.68 \\
\hline
\end{tabular}

${ }^{1}$ TS0 diet $=0 \%$ stover and $18.6 \%$ grain; TS $4=4.4 \%$ stover and $14.6 \%$ grain; TS $8=8.6 \%$ stover and $10.7 \%$ grain; and TS12 $=12.9 \%$ stover and $6.7 \%$ grain.

${ }^{2} \mathrm{SED}=$ standard error of the difference.

${ }^{3}$ Main effect, linear, and quadratic effects of diet.

\section{CONCLUSIONS}

Treatment of corn stover with $\mathrm{CaO}$ was effective at allowing significant amounts of corn stover to be used in the lactating cow diets without affecting NDF digestibility. Under the conditions of this study, ration fiber digestibility was maintained but overall DM and $\mathrm{OM}$ digestibility was reduced, leading to reduced intake and lactation performance. The significant effects of substituting $\mathrm{CaO}$-treated corn stover for corn grain related to intake, rumen kinetics, ruminal $\mathrm{pH}$, and total-tract digestibilities were linear and without significant interactions. This indicates that data from this study could be used to determine the potential incremental effect on digestion and nutrient supply to the cow of replacing corn grain with treated corn stover up to $12 \%$ of diet DM. Although the results of this and other studies would indicate that lactation performance may suffer with substitution of stover for grain, the present data provide information which nutritionists may use to predict the effect on lactation performance under different feed availability and economic constraints.

\section{ACKNOWLEDGMENTS}

We thank the ADM Company (Decatur, IL) for the funding that supported this project, and J. W. Pitas of the USDA Agricultural Research Service (Madison, WI) for technical support.

\section{REFERENCES}

AOAC. 1990. Official Methods of Analysis. 15th ed. AOAC Int., Gaithersburg, MD.

AOAC International. 2006. Official Methods of Analysis. 18th ed. AOAC Int., Gaithersburg, MD.

ASABE. 2007. Method of determining and expressing particle size of chopped forage materials by screening. ANSI/ASAE S424.1:663665 .

Brown, W. H., S. S. Khalaf, A. Marmolejo, R. S. Swingle, and F. M. Whiting. 1990. Partial replacement of alfalfa hay with chopped wheat straw in diets for lactating dairy cows. J. Dairy Sci. 73:31723177. http://dx.doi.org/10.3168/jds.S0022-0302(90)79007-8.

Cameron, M. G., G. C. Fahey, J. H. Clark, L. L. Berger, and N. R. Merchen. 1991. Effects of treating oat hulls with alkaline hydrogen peroxide on intake and digestion by midlactation dairy cows. J. Dairy Sci. 74:177-189. http://dx.doi.org/10.3168/jds.S00220302(91) 78159-9

Cameron, M. G., G. C. Fahey, J. H. Clark, N. R. Merchen, and L. L. Berger. 1990. Effects of feeding alkaline hydrogen peroxide-treated wheat straw-based diets on digestion and production by dairy cows. J. Dairy Sci. 73:3544-3554. http://dx.doi.org/10.3168/jds. S0022-0302(90)79054-6.

Canale, C. J., S. M. Abrams, L. D. Muller, W. L. Kjelgaard, P. M. Anderson, and H. W. Harpster. 1988. Alkali-treated forage for early lactation dairy cows: Effect on lactation performance and nutrient digestibility. J. Dairy Sci. 71:2166-2174. http://dx.doi. org/10.3168/jds.S0022-0302(88)79789-1.

Canale, C. J., S. M. Abrams, G. a. Varga, and L. D. Muller. 1990. Alkali-treated orchardgrass and alfalfa: Composition and in situ digestion of dry matter and cell wall components. J. Dairy Sci. 73:24042412. http://dx.doi.org/10.3168/jds.S0022-0302(90)78924-2. 
Donkin, S. S., A. Headley, H. Tucker, P. Doane, and M. Cecava. 2012. Processed corn stover as a corn silage replacement feed for lactating dairy cattle. J. Dairy Sci. 95(Suppl.):606. (Abstr.)

Ferreira, G., and D. R. Mertens. 2007. Measuring detergent fibre and insoluble protein in corn silage using crucibles or filter bags. Anim. Feed Sci. Technol. 2:335-340. http://dx.doi.org/10.1016/j. anifeedsci.2006.04.010.

Haddad, S. G., R. J. Grant, and S. D. Kachman. 1998. Effect of wheat straw treated with alkali on ruminal function and lactational performance of dairy cows. J. Dairy Sci. 81:1956-1965. http://dx.doi. org/10.3168/jds.S0022-0302(98)75769-8.

Haddad, S. G., R. J. Grant, and T. J. Klopfenstein. 1994. Digestibility of alkali-treated wheat straw measured in vitro or in vivo using Holstein heifers. J. Anim. Sci. 72:3258-3265.

Hall, M. B. 2009. Determination of starch, including maltooligosaccharides, in animal feeds: Comparison of methods and a method recommended for AOAC collaborative study. J. AOAC Int. 92:42-49.

Hall, M. B., and L. E. Chase. 2014. Responses of late-lactation cows to forage substitutese in low-forage diets supplemented with byproducts. J. Dairy Sci. 97:3042-3052. http://dx.doi.org/10.3168/ jds.2013-7539.

Huhtanen, P., K. Kaustell, and S. Jaakkola. 1994. The use of internal markers to predict total digestibility and duodenal flow of nutrients in cattle given six different diets. Anim. Feed Sci. Technol. 48:211-227. http://dx.doi.org/10.1016/0377-8401(94)90173-2.

Jackson, M. G. 1977. Review article: The alkali treatment of straws. Anim. Feed Sci. Technol. 2:105-130. http://dx.doi. org/10.1016/0377-8401(77)90013-X.

Latham, M. J., D. G. Hobbs, and P. J. Harris. 1979. Adhesion of rumen bacteria to alkali-treated plant stems. Ann. Rech. Vet. 10:244-245.

Lopes, F., D. E. Cook, and D. K. Combs. 2015. Validation of an in vitro model for predicting rumen and total-tract fiber digestibility in dairy cows fed corn silages with different in vitro neutral detergent fiber digestibilities at 2 levels of dry matter intake. J. Dairy Sci. 98:574-585. http://dx.doi.org/10.3168/jds.2014-8661.

Matis, J. H., and T. E. Wehrly. 1979. Stochastic models of compartmental systems. Biometrics 35:199-220.

Mertens, D. R. 1987. Predicting intake and digestibility using mathematical models of ruminal function. J. Anim. Sci. 64:1548-1558.
NRC. 2001. Nutrient Requirements of Dairy Cattle. 7th rev. ed. National Academy Press, Washington, DC

Oba, M., and M. S. Allen. 2000. Effects of brown midrib 3 mutation in corn silage on productivity of dairy cows fed two concentrations of dietary neutral detergent fiber: 2. Chewing activities. J. Dairy Sci. 83:1342-1349. http://dx.doi.org/10.3168/jds.S00220302(00)75001-6.

Pond, K. R., W. C. Ellis, J. H. Matis, H. M. Ferreiro, and J. D. Sutton. 1988. Compartment models for estimating attributes of digesta flow in cattle. Br. J. Nutr. 60:571-595. http://dx.doi.org/10.1079/ BJN19880129.

Rexen, F., and K. Vestergaard Thomsen. 1976. The effects on digestibility of a new technique for alkali treatment of straw. Anim. Feed Sci. Technol. 1:73-83. http://dx.doi.org/10.1016/03778401(76)90009-2.

Russell, J., D. Loy, J. Anderson, and M. Cecava. 2011. Potential of chemically treated corn stover and modified distiller grains as a partial replacement for corn grain in feedlot diets. Iowa State University Animal Industry Report. A.A. Leaflet R2586.

Shreck, A. L. 2013. Use of alkaline treated crop residues as partial grain replacements for finishing cattle. PhD Diss. University of Nebraska, Lincoln.

Taylor, C. C., and M. Allen. 2005. Corn grain endosperm type and brown midrib 3 corn silage: Ruminal fermentation and N partitioning in lactating cows. J. Dairy Sci. 88:1434-1442.

USDA. 2013a. Crop production 2012 summary (January 2013). National Agricultural Statistics Service, Washington, DC.

USDA. 2013b. Feed grains data: Yearbook tables. Economic Research Service, Washington, DC.

Wanapat, M., F. Sundstøl, and J. Hall. 1986. A comparison of alkali treatment methods used to improve the nutritive value of straw. II. In sacco and in vitro degradation relative to in vivo digestibility. Anim. Feed Sci. Technol. 14:215-220. http://dx.doi. org/10.1016/0377-8401(86)90094-5.

Weimer, P. J., Y. Shi, and C. L. Odt. 1991. A segmented gas/liquid delivery system for continuous culture of microorganisms on solid substrates, and its use for growth of Ruminococcus flavefaciens on cellulose. Appl. Microbiol. Biotechnol. 36:178-183. 